\title{
THE SOCIETY'S BUSINESS
}

Report of the Annual General Meeting held on WedNESDAY, 22ND APRIL, 1959, AT 5 P.M.

The Marquess of Willingdon, President, in the Chair.

1. The Minutes of the last Annual General Meeting were read, confirmed and signed by the Chairman.

2. Auditors' Report.-The Chairman proposed and it was carried unanimously that the Report of the Auditors and the Accounts for the year ending 31st December, 1958, be approved and adopted.

3. Rules of the Society.-The following amendments were made :-

Rule 2 (Membership) to read: The name of any member whose subscription is one year in arrears shall be removed from the list of members.

Rule 7 (Finance) to read : Subject to confirmation of their actions by Council, the Officers and Secretary of the Society are jointly empowered to invest the funds of the Society, to vary investments held and to realize such investments as may from time to time be necessary.

4. Annual Report.-The Chairman proposed and it was carried unanimously that the Report of the Council for the year ending 31st December, 1958, be approved and adopted.

5. Election of Officers.- It was proposed by Mr. A. R. LlewellinTaylour, seconded by Mr. E. P. Field and carried unanimously, that the Marquess of Willingdon be re-elected President of the Society and Mr. I. D. Malcolmson re-elected Honorary Treasurer.

6. New Members of Council.-It was proposed by the Chairman and carried unanimously that the following elections to Council be confirmed :-

James Fisher, Esq.

Dr. L. Harrison Matthews.

E. O. Shebbeare, Esq.

7. Immediately after the Annual General Meeting, Mr. F. D. Lovatt-Smith gave an interesting lecture on "Water, The Artery of National Parks ".

The Chairman proposed a vote of thanks to Mr. Lovatt-Smith which was carried with acclamation. 


\section{Dr. Willard van Name}

Our members will have read in "Editorial Notes" a short appreciation of our late Vice-President's work for our cause. We here gratefully record his last gift to our Society, a legacy of $\$ 11,000$.

\section{Christmas Cards}

The Society is most grateful to Miss Robin Tomkinson, Mr. Maurice Wilson and Mr. L. P. Warland for so kindly giving the pictures for the subjects of this year's Christmas cards. Order forms will be found in this number of Oryx.

\section{General Meetings}

The thanks of the Society are offered to the following :-

Dr. A. W. F. Banfield, Chief Zoologist, Canadian Wildlife Service, for his illustrated lecture on the 16th June, 1959. Subject: "Wild Life Conservation in the Rocky Mountains National Parks of Canada."

Mr. Mervyn Cowie, Director of the Royal National Parks of Kenya, for his lecture on 7th October, 1959. Subject : "Wild life preservation in East Africa : The present position."

Mr. Charles Lagus and the British Broadcasting Corporation for exhibiting to the Society the film Kariba, on rth October, 1959.

\section{Wild Life Films}

The film library consists of the following $16 \mathrm{~mm}$. films and two $35 \mathrm{~mm}$. film strips. All are coloured unless otherwise stated. They may be borrowed by members and others.

\section{Silent Films (with Captions)}

" The African Elephant." 10 minutes.

"Wild Life in East Africa." 30 minutes.

"Wild Life in Southern Rhodesia." Elephants and other animals in the Wankie National Park, with a commentary. 15 minutes.

"Wild Animals of the Indian Jungle." 20 minutes.

"Foxes and Badgers." 11 minutes.

"Animals of Australia." 10 minutes, black and white.

"Wild Camels of Mongolia." 4 minutes. 


\section{Sound Films}

"Kinship of the Creature." The animals of East Africa, with a plea for their conservation. 30 minutes.

"South Africa's Game Parks." A tourist film of the Kruger National Parks and the Hluhluwe Reserve. 16 minutes.

"Wild Life Sanctuary." A new film of the Kruger National Park, most kindly lent to the Society by the South African Information Service, Pretoria. 25 minutes.

"Expedition Moose." The protection of the moose in Ontario, Canada. 18 minutes.

"Ring-necked Pheasant." The life-history in Canada of the introduced ring-necked pheasant. 12 minutes.

"Heritage of Natal and Zululand." A tourist film of the Natal National Parks. 12 minutes.

"Wild Life in Uganda." 12 minutes.

"Stronghold of the Wild." East African animals and the work of the game departments. 35 minutes, black and white.

"Down in the Forest." Australia (Kangaroos). 6 minutes.

"Kaziranga." The wild animals of the Kaziranga Sanctuary, Assam. 12 minutes.

\section{5 mm. Film Strips}

"Wild Life in East Africa." Twenty-five coloured pictures of animals, with a written commentary, suitable for an hour's talk.

"The Ceylon Elephant." A plea for the preservation of the elephant in Ceylon. Twenty-six pictures, with a written commentary, suitable for an hour's talk. Black and white. 